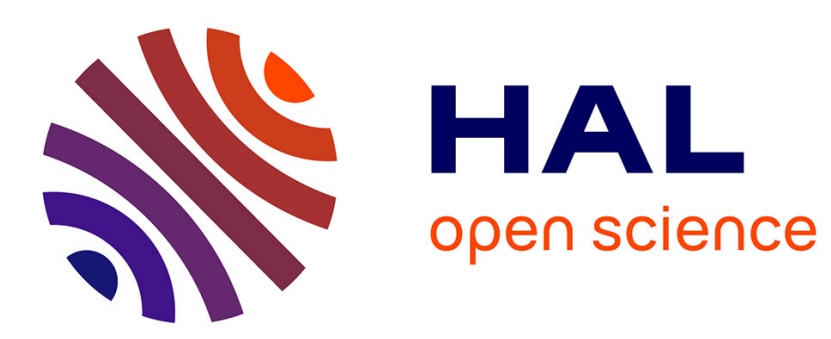

\title{
DISENTANGLING DISCRIMINATION ON SPANISH BOARDS OF DIRECTORS
}

\author{
Ruth Mateos de Cabo, Ricardo Gimeno, Lorenzo Escot
}

\section{To cite this version:}

Ruth Mateos de Cabo, Ricardo Gimeno, Lorenzo Escot. DISENTANGLING DISCRIMINATION ON SPANISH BOARDS OF DIRECTORS. Corporate Governance: An International Review, 2010, 19 (1), pp.77. 10.1111/j.1467-8683.2010.00837.x . hal-00613806

\section{HAL Id: hal-00613806 https://hal.science/hal-00613806}

Submitted on 6 Aug 2011

HAL is a multi-disciplinary open access archive for the deposit and dissemination of scientific research documents, whether they are published or not. The documents may come from teaching and research institutions in France or abroad, or from public or private research centers.
L'archive ouverte pluridisciplinaire HAL, est destinée au dépôt et à la diffusion de documents scientifiques de niveau recherche, publiés ou non, émanant des établissements d'enseignement et de recherche français ou étrangers, des laboratoires publics ou privés. 


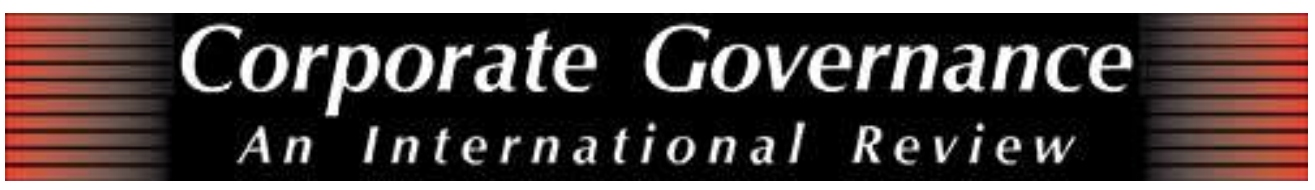

\section{DISENTANGLING DISCRIMINATION ON SPANISH BOARDS OF DIRECTORS}

\begin{tabular}{|r|l|}
\hline Journal: & Corporate Governance: An International Review \\
\hline Manuscript ID: & CGIR-2009-0342.R4 \\
\hline Manuscript Type: & Original Manuscript \\
\hline Keywords: & $\begin{array}{l}\text { Board Composition < Internal CG: Board of directors issues, Spain } \\
\text { < Governance Environments, Family ownership < Internal CG: } \\
\text { Ownership Issues }\end{array}$ \\
\hline \multicolumn{2}{|l}{} \\
\hline
\end{tabular}

\section{SCHOLARONE \\ Manuscripts}


DISENTANGLING DISCRIMINATION ON SPANISH BOARDS OF DIRECTORS

\section{Manuscript Type: Empirical}

Research Question/Issue: This study seeks to find evidence of discrimination behind the scarce presence women on Spanish boards of directors through factors within firms linked with different theories of discrimination.

Research findings/Insights: Using data on the boards of directors from the top 1000 Spanish companies in 2005 and 2008, we identify some signals of discrimination. We find that women directors are scarcer in those sectors where there are less female managers or where the directors are mainly draw on the firm's executive staff. There is also evidence of the dynamics of Becker's theory of discrimination, since time and competition seem to play in favour of women's presence on Spanish boards. We also find a contagion effect, implying a positive relationship between the number of women already on the board and the likelihood of adding a woman. This could signal some kind of underestimation of women's skills and preconceptions about their attitudes (such as risk-aversion) and hence their capacity to hold these positions.

Theoretical/Academic Implications: This study provides empirical support for the prediction of Becker's theory of discrimination. The study also furnishes evidence in favour of the existence of false preconceptions concerning the skills and risk attitudes of female managers.

Practitioner/Policy Implications: In order to reduce discrimination before reaching the board we propose to implement education and mentoring initiatives to improve the training of the female candidates, to improve the work- and family-life balance. Once they are included in the pool of candidates the implementation of good corporate governance practices related to transparency and objectivity in selection procedures and/or even the establishment of a women's quota on boards may contribute to dismiss employers' negative beliefs about the capabilities of female candidates.

Key words: Corporate governance; Gender Discrimination; Board of Directors; Glass Ceiling.

Classification JEL: G34, J16, M14, C35. 


\section{INTRODUCTION}

The objective of this paper is to find evidence of gender discrimination on the boards of directors of the largest Spanish companies through the analysis of observable factors related to their presence on boards and their possible relationship with the different types of discrimination provided by the literature. To do this, we analyse the composition (both in 2005 and 2008) in terms of gender of the boards of directors of the top 1,000 Spanish companies, where we have found a percentage of women that ranges from $6.6 \%$ to $8.6 \%$. When seeking to identify possible causes of female underrepresentation, we opt to study determinants on the demand rather than the supply side. Supply-side determinants relate to the tendency of women to participate less in the labour market and to their relative lack of long-term career commitment when compared with men, mainly as a consequence of motherhood, child care and the unequal allocation of household tasks. In looking for these kinds of causes, survey data, such as that of Bertrand, Goldin, and Katz (2009) are a useful reference. However, survey data are likely to be biased by the self-selection of those women who wish to 'showcase' their successful careers ${ }^{1}$. Besides, once a woman has reached the top executive rank, it is reasonable to assume that such supply-side differences are minimised and that such men and women are likely to be similar, sharing a high level of job motivation and lofty career ambitions (Bertrand \& Hallock, 2001). Hence, additional causes on the demand side should be explored.

The study of gender discrimination on the boards of directors of Spanish companies is important for a variety of reasons. Firstly, in today's corporate world, gender diversity has become a relevant topic at a time when a number of market regulators are considering quotas for women on publicly traded companies' boards as a requirement in their Codes of Conduct, and when improving governance is a key issue for firms to survive in a global crisis. In Spain this is a hot issue since the government, by introducing in 2007 the 'Equality Law' (Constitutional Act 3/2007 of 22 March 2007 for Effective Equality between Women and Men), has undertaken to raise female representation on publicly traded companies' boards to 40 per cent by 2015 , although this female quota is not mandatory but merely a recommendation. Secondly, the study of women's representation on boards is especially interesting as an extreme case in the broad research of possible causes of discrimination against women in the labour market. In fact, many studies (Adams \& Ferreira, 2004; Carter, Simkins, \& Simpson, 2003; Farrell \& Hersch, 2005) have addressed the differences in gender and race compositions 
of boards of directors. Terjesen, Sealy and Singh (2009) offer a thorough review of the literature on women on corporate boards. And finally, the causes of discrimination in labour markets remain an open issue, where no clear evidence has been found to favour one theory over another. Indeed, the characteristics of the different types of discrimination are usually mixed and distorted by elements of segregation (vertical and horizontal) in the labour market. In view of this, the key is to identify the type of discrimination that occurs in the labour market since different kinds of discrimination have different economic implications and imply diverse policy actions for policymakers.

The Spanish case offers a suitable setting for distinguishing among different causes of discrimination. In the Spanish business environment, women's economic integration remains a cause for concern given the marked lack of women in the higher decision-making positions (de Anca, 2008). While data from the quarterly survey of the labour market conducted by the Spanish national statistics office show that women's participation in the Spanish labour market has steadily increased from $28 \%$ in 1976 to $44 \%$ in 2009, the same increase is not observed in directorships and, especially, on boards of directors. According to the World Economic Forum 2009 Gender Gap report (Hausmann, Tyson, \& Zahidi, 2009), Spain ranks $90^{\text {th }}$ out of 134 countries in terms of Economic Participation and Opportunity and $120^{\text {th }}$ in terms of wage equality. In this sense, according to the Spanish Women's Institute's 2006 data, while the participation of women in executive positions of companies and the public sector is around $32 \%$, it is only between $6 \%$ and $8 \%$ on the boards of directors of the largest Spanish companies in 2005 and 2008, respectively, according to our estimates (see Table 1 for previous reports on women's presence on Spanish boards of directors). This proportion is one of the lowest among developed countries. In fact, Terjesen and Singh (2008) shows that Spain has the $8^{\text {th }}$ lowest percentage of women on boards among 43 countries studied, ahead only of Japan, Italy, Luxembourg, Iceland, Ireland, Austria and Argentina.

[Insert table 1 about here]

Nevertheless, the disadvantageous economic position of women in Spain does not equate to that exhibited in other social realms. In this respect, the WEF report shows that Spain ranks $9^{\text {th }}$ regarding political empowerment $\left(6^{\text {th }}\right.$ for women in ministerial positions with $44 \%$ female representation, and $11^{\text {th }}$ in women in parliament with $36 \%$ of female members), and in terms of education it occupies first position for level of enrolment in secondary and tertiary education (96\% and $76 \%$ of all women 
respectively). Therefore, there may be something in the economic area of Spanish society explaining this disparity.

Several theories explain this under-representation of women in the corporate world, based on adverse selection (women's incentive problems in the labour market) leading to self-fulfilling prophecies about their professional development. Moreover, De la Rica, Dolado, and Llorens (2008) find evidence that discrimination against women plays a key role in the Spanish labour market when explaining differences across gender, despite the fact that men and women are ex-ante identical. Given that outcome, we focus our study on the possible presence of a 'glass ceiling', (Morrison, White, \& Van Velsor, 1987; Powell \& Butterfield, 1994) as a crucial factor behind the scant presence of women on Spanish corporate boards.

We contribute to the literature on gender discrimination on Boards of Directors in several respects. Firstly, when looking for signals of discrimination on Spanish boards of directors we try to disentangle the mechanisms through which this might be taking place resorting to alternative theoretical models. In this sense, we take a step forward from similar studies by going into a level of detail which, to the best of our knowledge, no other study has achieved. Secondly, we control for a wider range of explanatory variables than the extant literature, which concentrates almost exclusively on visually observable firm characteristics. In this sense, we include variables that add features of the firm's industrial sector, such as industry competition (the HerfindahlHirschmann Index) and the proportion of female directors in an industry, along with a variable to control for the exogenous shock caused by the introduction in 2007 of the 'Equality Law'. And finally, unlike previous studies which mainly focus on Spanish listed companies or on a small sample of the largest Spanish companies, we focus on the top 1000 Spanish companies using similar criteria to those of the countries that usually monitor diversity on boards as an indicator of good corporate governance. The result of this is a database of unparalleled size and extensive scope in Spain (Catalyst gathers large scale data on women on boards in its Annual Census of the Fortune 500, but from US firms) that comprises more than 6000 board members in 2005 and around 5300 in 2008, with information collected from different sources (the SABI database, the files from the Mercantile Registry, e-Informa database, companies' annual reports and websites). This comprehensive database has allowed us to expand the number and the types of companies compared with previous studies and to estimate, through discrete outcome models, the probability of a directorship being held by a woman. 
The rest of the paper is organised as follows. In the next section, we review the theoretical models of discrimination and develop our hypothesis drawing on these theories. We then describe the data and the methodology of sample selection, and define the independent variables used. In the following section, discrete outcome models (negative binomial regression models) are used to estimate the probability of a director being a woman along with two additional models to gain further evidence for Becker's predictions and the contagion effect. Finally, we discuss the results obtained and present the main limitations and future research lines.

\section{THEORETICAL MODELS OF DISCRIMINATIONAND HYPOTHESIS DEVELOPMENT}

In corporate governance, the concept of diversity relates to board composition and refers to the mix of attributes, characteristics and expertise contributed by individual board members in relation to board procedures and decision-making (Van der Walt \& Ingley, 2003). In the widest sense, the various types of diversity in the boardroom include gender, age, ethnicity, race, nationality, culture, religion, constituency representation, independence, professional background, knowledge, technical skills and expertise, commercial and industry experience, and career and life experience (Milliken \& Martins, 1996; Dalton, Daily, Ellstrand, \& Johnson, 1998; Point \& Singh, 2003; Singh, Terjesen, \& Vinnicombe, 2008). In this paper we focus on the first of these. Progress towards more diversified boards in terms of gender has been slow and efforts to diversify boards away from homogeneous, closed and elitist cultures have encountered many difficulties. Many explanations may lie behind the low representation of women on boards of directors. In the first place, there may be a limited proportion of women with the professional profile desired by the company to join the board and therefore, they are generally excluded from the pool of potential executive candidates to hold these positions. Generally, candidates to the board of directors are required to have, among other prerequisites, a high level of previous experience in positions of responsibility in departments such as production and finance, whereas the heads of departments in other areas, like human resources or marketing, where there is a greater presence of women, are not considered to the same degree as potential candidates to hold directorships.

The second explanation is discrimination due to preferences. In this sense, the company may discard female candidates for its board of directors even when they are 
available because the decision-makers prefer forfeiting income rather than hiring women (Becker, 1957). The third explanation for the scarce presence of women on boards is due to the fact that the abilities of women candidates are not correctly assessed. This includes statistical discrimination defined by Phelps (1972) that occurs when women are judged according to the average characteristics of their group and not on the basis of their own personal characteristics; and also the closely related mistakebased discrimination with respect to the systematic underestimation of women's skills (Wolfers, 2006).

\section{The reduced pool of female candidates limits their presence on the board.}

Regarding the first group of explanations, which we call 'reduced pool of female executive candidates', the limited presence of women on boards of directors would not be due so much to gender discrimination in the selection process as to the existence of socio-cultural obstacles in the early stages leading up to the professional promotion of women. Nevertheless, even in a context without discrimination, it is an empirical (and unresolved) question whether this is efficient or not. In fact, some authors (Rodríguez Mora, 2009) argue that, even if there were no discrimination, an outcome where female participation is scarce would be inefficient insofar as the preferences and outlook on life that women have are a consequence of 'nurture' (they are brought up in certain ways) and not 'nature', that is, because of their inherent condition of being women.

Among the factors that explain why there are fewer women than men with the potential to be appointed to boards of directors, there are some explanations, such as the existence of occupational segregation (Dolado, Felgueroso, \& Jimeno, 2004), which reduce the proportion of women in finance-related or more technical positions, which are precisely those functions more likely to be represented on a corporate board. Bertrand and Hallock (2001) state that there are differences between men and women that could prevent the development of a successful executive career, such as women's relative lack of long-term career commitment possibly induced by lower wages, or a greater taste for fringe benefits or good working conditions, family responsibilities that, in many cases, unlike with men, interrupt the development of the professional activity of the female worker, or the anticipation by many women of the glass ceiling that drives them to sacrifice their professional development in favour of their family life (according to data from Spanish Woman's Institute, in 2006 Q4, among the people who were not seeking employment due to family reasons, $97 \%$ were women, with women also 
requesting leave in $98 \%$ of cases of maternity/paternity leaves). All of them mean that there is a lower proportion of ready-for-the-board female executives.

If there is a shortage of suitable-prepared female executives, we would expect to find a lower proportion of female directors among those economic sectors where there is a lower supply of female managers.

\section{Hypothesis 1.1: There is a positive relationship between the industry proportion} of female executives and the proportion of women on the board.

Additionally, the special characteristics of the pool where the companies chose board members are important when determining the effect of the reduced pool of women candidates on the percentage of women on the board. So, in those firms where the board members are filled mainly among the owners of the firm do not apply the restriction of a reduced pool of women in the executive management. This is the case of family-based firms, where the pool of candidates for the board comes from family ties and where women board members assume at the same time their roles as managers and as owners. In this sense, insofar as in family-based firms female executive candidates to the board are drawing on the owners-managers women family members females find a easier access to the board and we should expect a greater presence of women on their boards compared to the rest of companies. Ruigrock, Peck, and Tacheva (2007) found that in Swiss family-based companies in which women with family ties were more likely to have access to boards and where the owners have a greater control of the company and managers are less likely to be on the board, female directors will make up a higher proportion of the board.

Hypothesis 1.2.: Family-based firm variable has a positive relationship with the proportion of women directors.

Lack of competition hinders the presence of women on the board. The reduced pool of female candidates could imply that the number of women who are actually willing and able to hold a position on boards of directors is not equal to that of men. Nevertheless, considering that the population of female executives $(31.7 \%$ according to the Spanish Woman's Institute 2006 data) is a good proxy of directors' eligibility, a proportion higher than the actual 6-8\% should be expected for women's presence on boards. Therefore, the significant gap between these figures points to the possibility of some kind of discrimination against women.

We label the first group of discrimination drivers as 'discrimination for preferences'. According to Becker's theory of discrimination (Becker, 1957), we refer 
to cases where those responsible for appointing board members have a dislike for female directors, sacrificing efficiency in order to select people they "like" instead of people they "need". Thus, the Becker theory predicts that the discriminatory practices (what he called taste-based discrimination) of those companies that prefer not to work with women would lead to higher costs, in terms of loss of efficiency and lower profits, than those of companies that did not discriminate. Consequently, in a perfectly competitive market, the companies that discriminated would not survive in the long term.

The usual criticism of Becker's theory focuses on the point that discrimination, implying higher costs or diminished income, should have disappeared as a result of market dynamics, since time and competition would ultimately resolve the problem of discrimination in the long run. In spite of this, Heckman (1998) argues that this prediction may not be false in the end. According to this author, discrimination will only disappear in the presence of strong competition and even then it may take decades to remove inefficient companies (such as those that discriminate) from the market. In less competitive markets, extra rents allow companies to indulge their tastes, and therefore discrimination can be seen as an affordable option for those who like it even when this is uneconomical. Cavalluzo, Cavalluzo, and Wolken (2002) found that African Americans were more likely to be denied credit in less competitive financial markets (those more concentrated). Thus, in our empirical study we look for signs of lower numbers of female directors among less competitive sectors. Using the level of industry concentration as an inverse indicator of competition we can formulate the following hypothesis:

Hypothesis 2.1. An industry's level of competitive concentration has a negative relationship with the percentage of women on the board

Additionally, according to Heckman's (1988) proposition, market dynamics will take some time to work through before removing a new company with discriminating practices from the market. Indeed, among start-ups one could find all type of companies, discriminating, and non-discriminating ones. Those less inefficient companies have higher chances of surviving. As long as we consider discriminating practices as inefficient, we expect a lower presence of women among younger companies and a higher proportion of women on boards among older ones, because only in older companies the detrimental effect of discrimination would have reduced their chances of survival and only the non-discriminating ones remain in the market. 
Hypothesis 2.2. The firm's age has a positive relationship with the proportion of women directors.

\section{Lack of information about actual personal abilities raises barriers against}

female candidates. Sometimes, the absence of female directors does not stem from an act of deliberate discrimination or preference for male directors, but as a consequence of an underestimation of women's skills. This underestimation is linked with diverse theories of discrimination. For instance, according to statistical discrimination (Phelps, 1972), the company that seeks to maximise its expected profit will discriminate against women if it believes them to be less qualified on average than men, or if the cost of gaining information about the individual applicants is excessive. Thus, the company will look for easily observable variables (i.e. gender), instead of personal characteristics, which may reflect biased inferences on the part of the company and have nothing to do with productivity or information. Although there may be some economic rationality to this, inefficiencies can also be involved, as the a priori preference for male over female candidates might not only stem from the employer's previous statistical experience with the two groups, but also from the prevailing sociological beliefs concerning the abilities of women and from prejudices about them in society.

Closely related to this is mistake-based discrimination. Biased knowledge about female candidates has its roots in stereotyped profiles of men and women that have no real and objective basis. Therefore, if the low representation of women on the board were caused by this type of discrimination, the companies involved would be inefficient in their resource allocation, entailing a clear cost for them. We, therefore conclude that, given an underestimation of women's skills, in those cases where board nomination committees have some additional information about candidates, women's presence is substantially higher. This information prevents women from being assessed in terms of some kind of average of a female group or stereotype.

If there are stereotypes and social prejudices that bias the perception of women's abilities, this bias tends to disappear if more women are already on the board, since direct contact with people of the discriminated group, and the information provided by this, can offset the effects of social stereotypes and prejudices (Bertrand, Dolly, \& Mullainathan, 2005). According to this contagion factor, we are more likely to observe the addition of a woman to the board the higher the previous existing representation of women on the board. 
Hypothesis 3.1. The absence of women on the board has a negative relationship with the probability of hiring new female candidates.

One example of this underestimation of women's skills that can be easily tested is to look at risk-aversion. The perception that women are more risk-averse than men (Jianakoplos \& Bernasek, 1998; Sundén \& Surette, 1998) is considered by some authors as a stereotype and as a major cause of the 'glass ceiling' on corporate promotion ladders (Johnson \& Powell, 1994). In this sense, Schubert, Brown, Grysler, and Brachinger (1999) found that, in contextual financial decisions, the preconceptions concerning the risk attitudes of female investors and managers may be more prejudice than fact, and they would be a source of statistical discrimination against women in financial and labour markets. The lower presence of women on the boards of firms engaged in riskier business can also be seen as a sign of statistical discrimination in the sense that, if women are expected to be more conservative investors than men, they are consequently excluded from those positions more concerned with risk-taking. This discrimination means that when a company faces a significant level of risk, it is less likely to hire women for the board, since they are wrongly seen as less skilled to make the risky decisions that may be necessary for a firm's success. To test whether riskaversion is a true stereotype, we expect the level of risk only to affect the hiring of new female directors in those companies with no woman on the board. By contrast, once women are on the board and their risk propensity can be correctly assessed by the whole board, there should be no effect of the level of risk on the gender of new board members.

Hypothesis 3.2. The risk level of the firm has no effect on the gender of new directors when there are already women on the board.

To sum up, Table 2 presents and summarizes all of the propositions and the hypotheses of our study and their relationship with the various theories of discrimination

[Insert Table 2 about here]

\section{SAMPLE AND DESCRIPTIVE STATISTICS}

\section{Data Selection}

In Spain, the board of directors is the chief governing body of a company, and it is appointed by the shareholders' meeting. The company's bylaws specify the composition and number of members of the board and how they are to be chosen. However, article 
116 of the Securities Market Law obliges Spanish listed companies to inform in their Annual Report on Corporate Governance on compliance with the official recommendations concerning corporate governance. According to this article, when dealing with aspects related to board practice and standards, Spanish corporations follow the 'comply or explain principle' (De Anca, 2008).

These recommendations were established in the Unified Code of Good Corporate Governance of Listed Companies approved by the CNMV (National Securities Markets Commission, the Spanish equivalent to the US Securities and Exchange Commission), in May 2006. This Code sets out recommendations concerning functional structure, size and board composition. The board should reflect the diversity of knowledge, gender and experience needed to perform its functions effectively, objectively and independently. For that reason, the board should ideally comprise no fewer than five and no more than 15 members; External directors (non-executive directors) - both proprietary and independent - should hold a large majority of board places. In particular, independent directors should account for at least one-third of all board members; Gender diversity has been introduced into the new code in Recommendation $n .15$ whereby when the number of female directors is low or zero, the board must explain the reasons and actions taken to correct the situation.

With reference to this gender diversity, the Code recommends that companies with a limited presence of women on their Boards should make a deliberate effort to find potential female candidates whenever a vacancy has to be filled (especially that of independent directors). In particular, the Nomination Committee must ensure that in the process of selecting new board members: a) there are no implicit biases preventing or impeding the selection of women; and b) companies will have to look intentionally for and include among potential candidates women with the professional profile sought. The Code also specifies more specialized procedures for the selection of new board members. Although the CNMV considers there have been significant improvements in corporate governance at listed Spanish companies, it also underlines the need to have better board transparency, in particular in the selection processes.

The present study focuses on Spanish companies whose operating revenues exceeded 100 million euros in the year 2003, according to the $\mathrm{SABI}^{3}$ database. This includes both listed and unlisted companies. We have chosen to analyse the largest companies because they mark a clear business and social reference. Small and mediumsized enterprises behave quite differently in terms of their corporate governance (Zahra, 
Neubaum \& Huse, 2000; Link, Netter \& Yang, 2008) and the quality of information deteriorates quite sharply when the size of the company analyzed shrinks. Additionally, the firm size criterion corresponds to those used in other countries that usually monitor diversity on boards as an indicator of good corporate governance, which makes for readier comparison with neighbouring countries. Also, this is the criterion of the economic literature for analysing diversity on boards. For example, Carter et al. (2003) use Fortune 1000 companies as their sample, while Farrell and Hersch (2005) base their study on Fortune 500 lists, as do Adams and Ferreira (2004).The search showed a total of 1148 non-financial companies, once companies that had closed down ${ }^{4}$ had been eliminated. In 2003 these companies had a total of 1.35 million employees, representing $10 \%$ of the total Spanish workforce. They also accounted for $65 \%$ of the companies with more than 5,000 employees, $40 \%$ of those with more than 1,000 and 30\% of those with more than 500. Their aggregate operating revenue was equivalent to $65 \%$ of GDP and accounted for $78 \%$ of the returns of Spanish companies.

Information on the board members of companies was also obtained from the SABI database ${ }^{5}$, as updated in June 2005 and June 2008. This interval of three years is the same used by Garay and Gonzalez (2008), to ensure mobility of the board members. In some cases, it was necessary to supplement that data with information obtained from files from the Mercantile Registry, e-Informa database, and companies' annual reports and websites.

In order to determine the gender composition of the boards, we examine the first names of the board members. Spanish first names clearly identify gender, even for those names with the same root they have a different suffix (i.e. Antonio for male, Antonia for female). And in the case of composite names, the order signals the gender (i.e. MaríaJosé for female and José-María for male). Therefore, the gender of almost all directors was clearly signalled by their first names. For those remaining (mainly foreign -e.g. Japanese, Korean, French and Scandinavian - names), the matter was clarified one-byone using internet search: by the use of gender-specific language in a biography given in the Annual Report (Mr, Ms, he, she, his, her, etc); by a photograph given in the Annual Report; by internet materials (mainly news articles and the websites of foreign companies). Institutional board seats held by other corporations are excluded, since they are represented by a changing group of individuals whose identities and gender are unknown. Thus, to measure the number of female board members, only individual direct members were counted. There were only 633 institutionally held board positions 
in 2005 out of $6,636(9.54 \%)$ and 675 in 2008 out of 5,952 (11.34\%) in the top 1148 companies. Additionally, under the hypothesis that the percentage of women among the total of individual direct members is, or should be, approximately the same as that found among the total administrators, it should not produce significant biases to exclude institutional board seats in the calculated percentage of female participation on boards. Therefore, the exclusion of these seats from this study has a relatively small impact on the proportion of women on the boards of directors of these companies - 63 companies were excluded for 2005, since all their boards were filled with institutionally designated directors. That left 1,085 companies suitable for the following analysis of gender composition. In 2008, 1076 companies out of the original sample of 1148 non-financial companies were still in existence (67 had liquidated, another four were in a liquidation process, and one had disappeared from the original sample because it was a joint venture that had been dissolved), and there were 84 companies whose boards were entirely made up of institutional board members, reducing the final sample to a total of 992 firms.

In addition, the functions of Commissioner (comisario), Manager/Administrator, General Manager and Secretary of the Board were eliminated from the sample of directors since these, as a general rule, do not qualify as board members when identified by SABI. The study regards as board members the functions of President, VicePresident, Executive Director, Administrator, Joint Administrator (Member of the Board), Sole Administrator and other functions (such as the Treasurer and those on the governing boards of three cooperative companies: COFARES, COREM and ANCOOP). With reference to those companies in which a sole administrator represents the board of directors, in the absence of a complete board, these companies are counted as having a board formed by a single individual within the set of board directors represented in this study.

With regard to the characteristics of the boards of directors (Table 3), we conclude that, in June 2005, just 6.61\% (397) of individual board directorships of the 6003 in the top 1085 Spanish companies were held by women. The average number of direct members per board was 5.53, of which only 0.37 were women, and only 255 companies $(23.5 \%)$ included at least one woman on their boards. Referring to the figures for June 2008, there has been a slight increase in the diversity of Spanish boards, since now $8.66 \%$ (457) of the 5277 individual seats on the boards of directors in the top 992 Spanish companies are held by women. 
[Insert Table 3 about here]

Between 2005 and 2008, 1,893 directors were appointed, 196 of them women $(10.35 \%)$. In the same period, 2,619 directors left boards, with just 5.19\% (136) of them female directors. This indicates that $56.4 \%$ of all the directors in the 2005 sample remained in their position in 2008 , but for female directors there was a higher retention rate, at $65.7 \%$ ). We use these data to analyze hypothesis 3 in the following section.

\section{Defining Independent Variables}

We identify various firm characteristics as independent variables in our models since previous research documents relationships between the representation of women on corporate boards and specific firm characteristics (Farrell \& Hersch, 2005). We use measures of board size, firm size, degree of independence with regard to shareholders, firm age, profitability, productivity by employee, firm risk, indebtedness ratio, public contracts, competition in the industry and its proportion of female directors.

Additionally, we include the following variables: the cooperative association form of the company; if the firm is stock market-listed; its family-based character; and industry control dummies. Descriptive statistics concerning these variables are shown in Table 4.

[Insert Table 4 about here]

The availability of financial variables (profitability, productivity, risk and indebtedness, as well as firm size) depends on the existence of a firm's financial statements, which in some cases (unlisted companies) are available to the public only with considerable delay. Therefore we lag these variables a minimum of two years to ensure we have data for all the firms in the sample. This lag has the added advantage of reducing the risk of possible endogeneity between these variables and female representation (Carter D’Souza, Simkins, \& Simpson, 2010; Garay \& González, 2008). In this way, we speak about causality in Granger's sense in such a way that financial variables produce the distinct proportion of women on boards of directors, and not vice versa. Additionally, firm effects and year dummies will help to reduce any bias on omitted variables (Carter D’Souza, Simkins, \& Simpson, 2010).

Board size is measured by the number of individual direct members on the board. We have also included the square of this variable to take into account possible non- linearities. There are multiple ways of defining firm size. The most common quantitative criteria to measure it are: number of employees, total assets and net income (Osteryoung \& Newman, 1993). We choose total assets, since this measure is an established way of accounting for differences in firm size and has been used in previous 
board-related studies (Agrawal \& Knowber, 2001; Carter et al., 2003). In order to avoid unusual results in one year distorting the measure, we calculate a two-year lagged threeyear mean.

Shareholder control in the company is measured by the Bureau van Dijk's Independence Indicator, which construct an indicator through its Database of Ownership to measure the degree of independence of the company in relation to its shareholders. The indicator is constructed as follows: the A indicator denotes the maximum degree of independence and is assigned when there are no shareholders registered with direct or complete ownership equal to or higher than $25 \%$ of the capital. It is also divided into $\mathrm{A}+, \mathrm{A}$ or $\mathrm{A}$ - based on the criteria that the higher the number of shareholders, the more difficult the control of a company. The B indicator is applied to companies in which none of the registered shareholders possesses $50 \%$ or more (direct or total) of the company's equity; again, this is classified as B+, B or B- depending on the identified number of shareholders. The $\mathrm{C}$ indicator is applied to a company with a registered shareholder who has more than $49.99 \%$ (direct or total), and also if a source indicates that there is a final ownership. Lastly, the indicator $U$ shows an unknown degree of independence. We categorize this variable using values from 1 to 6 , where 1 indicates the lowest grade of independence (C) and 6 the highest $(\mathrm{A}+)$.

Another variable used to characterize different attitudes toward the presence of women on boards of directors is the firm's age. To the best of our knowledge, while the relationship between time and discrimination is straightforwardly determined from the studies of Becker (1957) and Heckman (1998), no other paper has empirically analyzed this linkage. The firm's age is introduced into the model in logarithms because the main differences are expected in the early years of the company.

We select two ratios to measure firm performance: profitability, measured using the two-year lagged mean of the return on assets (ROA) over three consecutive years, computed as net income divided by total assets; and the three-year mean of productivity per employee, calculated as the ratio of operating revenues (in thousands of euros) per employee lagged two years.

We also include a measure of leverage: the first is the three-year average of the firm's indebtedness ratio lagged two years, computed as the long-term debts of the company divided by the share capital plus reserves. Furthermore, we study the level of risk, as the volatility of profitability, measured by the standard deviation of the annual ROA computed over a two-year lagged 13-year period. 
Additionally, we include the variable 'public contracts' to control for the exogenous shock caused by the introduction in 2007 of the Act for Effective Equality between Women and Men (Constitutional Act 3/2007 of 22 March 2007) by the Spanish government. This statute, in order to encourage the inclusion of women on company boards, provides that the government may give special priority when giving public contracts to those firms that promote labour market equality between women and men. To take into account the possible impact of this Act on those firms that undertake government contracts, we add the percentage accounted for by government contracts in total income between 2004 and 2006 as a new variable. If companies heed this statute, when government contracts represent a sizeable percentage of a firm's total income, then it may be more likely to have more women on its board.

We also include two variables that add features of the firm industry. One is competition. To compute this variable we have used the Herfindahl-Hirschmann Index (HHI) at industry level. The HHI measures industry concentration and it is a widely accepted measure of industry competition (Rhoades, 1993) as it decreases as industry competition increases. The HHI index is calculated as the sum of the squared market shares as a percentage of all firms in an industry (2-digit CNAE, Spanish equivalent of SIC codes) for 2003. We transform the variable to its natural logarithmic to avoid skewness. The second variable is the proportion of female directors in an industry (2digit CNAE), obtained from the Spanish Labour Force Survey for 2003.

We include three dummy variables in the models: family-based firm, listed company (quoted on a stock market) and cooperative association form since among the companies studied, the representation of women on the governing bodies of cooperative companies is greater than in any other type of company (i.e., public limited companies and limited liability companies). In the case of the family-based firm variable, we use the dimensions of ownership and power as a classification criterion (Gersik, Davis, Hampton, \& Lansberg, 1997). Thus, a company is considered a family-based firm when various members (at least two) of the same family hold seats on the board of directors and/or a significant portion of the shares of the company are owned by the same family. ${ }^{6}$ When a company is a subsidiary or is part of a family group, but no member of the family is on its board of directors, this company is not classified as a family-based firm since the family is not directly involved in its management. To verify the family nature of the companies in the sample analysed, we have the help of the Instituto de la Empresa Familiar (Family Business Institute), which checked our list against its 


\section{[Insert Table 5 about here]}

\section{MODELLING WOMEN'S PRESENCE ON BOARDS OF DIRECTORS}

The number of female directors on the board of a company $\left(y_{i}\right)$ can be modelled with a count data model. In the present case, where the variance of the dependent variable (the number of female directors) is higher than the mean, we estimate a negative binomial regression model (equation 1$)^{8}$. In this model the probability of finding $k$ women on the board of directors of a company is given by equation 1 ,

$$
\operatorname{Pr}\left[y_{i}=k\right]=\frac{\left(v \lambda_{i}\right)^{k}}{k !} e^{-v \lambda_{i}}
$$

This model is a generalisation of a Poisson regression model that adds a random variable $(v)$ with a Gamma distribution of parameters $1 / \alpha$ and $\alpha$ $(g(v) \sim \operatorname{Gamma}(1 / \alpha, \alpha))$ to account for the extra variability of the distribution. As in a Poisson distribution, $\lambda_{i}$ is the expected number of female directors on the board of company $i\left(E\left[y_{i}\right]=\lambda_{i}\right)$. The expectations of the dependent variable vary mainly with the size of the board $\left(n_{i}\right)$ that is considered as the exposure variable. Therefore, the expected number of female directors can be modelled (Equation 2) as the product of the number of directors $\left(n_{i}\right)$ and the proportion of women among them $\left(p_{i}\right)$. This latter variable $\left(p_{i}\right)$ can vary in accordance with a group of independent variables $\left(\mathbf{X}_{i}\right)$, referred to the whole company.

$\lambda_{i}=n_{i} p_{i}=n_{i} e^{\mathbf{X}_{i} \mathbf{\beta}}$

In this negative binomial model, parameter $\alpha$ allows us to quantify the grade of over-dispersion of variable $y_{i}$ (the greater $\alpha$ is, the greater the variance will be with respect to the mean). In this way, if $\alpha=0$, the negative binomial becomes a Poisson distribution (equal mean and variance). However, if $\alpha \neq 0$, then there is a so-called 
contagion effect, i.e. having a positive case makes it more probable that there will be further positive cases. This contagion factor can be derived from the case where the gender of each member of the board is not independent of the gender of the other members. We make use of this contagion effect as a sign that reinforces hypothesis 3.1, the presence of women on the board lessens barriers to other female candidates, although further test are presented in Table 8.

\section{[Insert Table 6 about here]}

Robust estimations of the negative binomial regression models are presented in Table $6^{9}$. The number of direct members of the board is used as the exposure factor $\left(n_{i}\right)$ in the negative binomial regression models. This implies that, although the independent variable is the number of direct members, the outcome of the regression, and the effects of the independent variables can be interpreted in terms of the expected proportion of female directors $p_{i}$, instead of the number of female directors $y_{i}$.

Moreover, we consider two possible specifications for the model. The first one (model I) uses pooled data from 2005 and 2008 to fit a negative binomial model with a single over-dispersion parameter common to all companies. The second (model II) uses panel data to fit a negative binomial model with a random-effects over-dispersion parameter that varies randomly from company to company. The results of both models are quite similar, and the tests to measure the goodness of fit, such as the Wald test or the likelihood test, show that the estimated models describe reasonably well the behaviour of the dependent variable (the proportion of women on boards of directors) even at a $1 \%$ significance level.

\section{RESULTS}

Regarding the interpretation of the significant explanatory variables in the models, we include four groups of variables: the control variables and the variables concerning hypotheses. Next we discuss the results for each of these explanatory variables of the proportion of women on boards of directors. To clarify the implications of the results, we compute the expected proportion of female directors in a case base company where variables are considered in their means (quantitative variables) and their modes (qualitative variables).

Beginning with the control variables, the number of direct members of the board is used as the exposure factor in the negative binomial regression models, but is added, 
as well, as an explanatory variable. In the latter role, we observe that it is effectively a significant explanatory variable, in which an increase in board size implies an increase in the proportion of positions held by women, as documented by Carter et al. (2003) and Agrawal and Knowber (2001). The variable is also significant (negatively) in squared terms, so an increase in board size only has an effect for small boards, since the effect on the proportion of female directors reaches a maximum when the board has around 20 to 25 members (see Figure 1).

As prior research suggests (Brammer, Millington, \& Pavelin, 2007; Fryxell \& Lerner, 1989; Harrigan, 1981), we find that the type of industry is significant in explaining the presence of women on corporate boards. Thus it turns out that industries with a higher presence of women (Financial services and real estate agencies, Consumer goods and Consumer services) are service-oriented, labour-intensive industries, while those with a lower presence are the more technical ones such as Oil and energy, Commodities, industry and construction, and Technology and telecommunications.

There was also a significant increase in the number of female directors between 2005 and 2008. Nevertheless, it is not possible to know whether this implies a tendency towards reducing the discrimination gap or just a discrete change. A possible explanation for this increase is related to the Equality Law. In this sense, if the Act were the main driver in the observed increase, this shift should be higher among companies where government contracts represent a sizable percentage of their total income, since it lays down that, to retain government contracts, those companies should have (among other things) a gender-balanced board by 2015 . Nevertheless, the variable that takes it into account (the share of public contracts in a company's income) has not implied a greater increase between 2005 and 2008.

\section{[Insert Table 7 about here]}

With respect to the influence of the Bureau van Dijk's Independence Indicator, given that in Spain the presence of activism in favour of diversity on the boards of directors by institutional shareholders is not detected, as Carleton, Nelson, and Weisbach (1998) and Gillan and Starks (2000) document in their studies, we consider a more likely cause is the fact that women in Spain tend to hold seats on boards as External Proprietary directors. The cooperative variable result can be explained by the practice of these companies of having representatives of the partners on the board on the basis of a democratic voting procedure (one member, one vote). 
Additionally, we find a (marginally significant) negative relationship between the presence of women on the board of directors and the fact of being a listed company (see Table 6), and the firm size variable. By contrast, Agrawal and Knowber (2001) found for the US a positive sign that they attribute to a greater demand for diversity directed at these companies through public opinion. Usually, these types of companies (large and listed) include a smaller proportion of proprietary directors on their boards while having a higher proportion of executives and independent directors, where women are under-represented.

Other control variables related to profitability (ROA) and productivity (turnover per employee) do not have a significant effect on the representation of women in Spanish boards. This result does not coincide with previous studies (Adler, 2001; Carter et al., 2003; Catalyst, 2004; Erhardt, Verberl, \& Shrader 2003), which found a positive relationship between female representation on the board and the company's performance. However, to test this hypothesis, the model specification should be the reverse, with profitability as the dependent variable and the gender composition of the board as a lagged independent variable as in Carter et al. (2003).

Regarding Hypothesis 1.1, the proportion of female executives in the industry has a positive (and statistically significant) effect on the expected number of female directors on the board. This result reinforces the hypothesis that a reduced pool of women candidates from executive positions diminishes the number of female members of the Board of Directors.

The results (see Table 6) confirm hypothesis 1.2. Family-based companies, where board members are chosen mainly among owners and where the pool of candidates stems from family ties and not from executive positions, has a positive relationship with the proportion of women directors. In fact, Family-based firm is the variable that has the greatest positive impact on the presence of women on boards of directors (see Table 6).

A reduced pool of female candidates is far from being the only explanation of the differences between companies in the observed number of female directors. As we have previously commented, theoretical arguments focused on the characteristics of the female labour supply (which we called the reduced pool of female executive candidates) cannot explain, on their own, the sizable gap found in women's participation in Spanish boards of directors. Therefore, when we interpret the sign and effect of the explanatory 
variables, we turn to the demand side for the role played by the distinct types of discrimination against women by linking the identified factors with alternative theories.

According to Becker's taste-based discrimination, as discriminating companies incur higher economic costs, in perfect competitive markets they tend to disappear. Hypothesis 2.1 states that there is a positive relationship between the proportion of women on the board and industry competition. The results in Table 7 and Figure 1 show that the level of industry concentration, measured by the HHI index, has a negative effect on the proportion of female directors. Since this index decreases with industry competition, the sign of the estimated coefficient is congruent with hypothesis 2.1 and also in line with the dynamics predicted by Becker's theory, that discrimination is less likely in competitive sectors.

As can be seen in the models of table 6 and figure 1, the age of the firm has a positive relationship with the proportion of women on the board (Hypothesis 2.2). This also reinforces the idea behind Becker's model of taste-based discrimination. The fact that older companies have more women on their boards seems to indicate precisely that companies that survive are those that integrate more diversity into their boards. By contrast, among younger ones it is easier to find both discriminating companies and those who do not discriminate ${ }^{10}$.

\section{[Insert Figure 1 about here]}

Hypothesis 3.1 states that the presence of women on the board helps to reduce statistical discrimination and other mistake-based discrimination. The estimated negative binomial models show that there is a positive and significant contagion effect. Likelihood ratio tests also confirm the existence of over-dispersion of the number of women on the boards of directors, since the negative binomial model is preferable to the simple Poisson regression model. By contrast, a likelihood ratio test against a zeroinflated negative binomial allows us to conclude that this later model is not better than the negative binomial model, and that the contagion factor is able to explain sufficiently the observed over-dispersion.

This significant contagion effect indicates that the presence of women on the board lessens barriers to other female candidates. That is to say, if there is a woman on the board, it is more likely that other women will be appointed to the same board. So far, there are at least three different causes for this contagion factor. The first two are hypothesised by Farrel and Hersch (2005). One, on the supply side, is that potential female candidates may be more attracted to firms that have already achieved some 
degree of board diversity. The other reason offered by these authors is on the demand side, bearing in mind that women board members may have an influence in hiring additional women to serve on the board, either by identifying their peers for nomination or by applying pressure. Alternatively, we consider a third explanation (also on the demand side) in line with the possible existence of a certain underestimation of women's skills, based on the fact that the previous presence of women on the board contributes to reducing the bias in the perception of their abilities (removing mistakebased discrimination).

Nevertheless, statistically speaking, an alternative source of the observed overdispersion in the negative binomial model is unobserved heterogeneity, derived from omitted variables. That is to say, unobserved heterogeneity ('spurious contagion') and 'true' contagion can generate the same negative binomial distribution of observed outputs. With a non-dynamic model, it is impossible to determine whether the observed over-dispersed distribution arose from true or spurious contagion (Long, 1997). In order to test whether there is a true contagion factor, we estimate a new dynamical model, where the appointment of a female director depends on the previous presence of women on the board. A true contagion effect implies that in those companies where there is a female director it is easier for a new woman to join the board.

Since our sample includes data from the boards of the same companies in 2005 and 2008, it is possible to compare the composition of both boards for each company, and at the same time to count the number of female and male directors leaving and joining the company's board (see Table 3 ).

The model specified is also a negative binomial model (Equations 1-2). The dependent variable in the new model is the number of female directors appointed by a company between 2005 and $2008\left(y_{i}\right)$ and the total number of directors appointed refers to the exposure variable $\left(n_{i}\right)$. As exogenous variables, we have included the proportion of women on the board in 2005, as well as the number of female directors that left the board in 2005. Farrell and Hersch (2005) use a similar framework, although with a Poisson model specification. Additionally, we include in the model the same variables considered in the previous sections for the gender composition of the board. Results of the model estimated are shown in Table 8.

[Insert Table 8 about here]

The results in Table 8 show that there is a positive relationship between the percentage of women already on the board and the likelihood of adding a woman to the 
board between 2005 and 2008, which strongly indicates that a 'true' contagion effect exists, and this confirms hypothesis 4 . This result is the opposite to that found by Farrell and Hersch (2005) for Fortune 500 companies, implying that companies in their sample tend to add women to their boards when they have low or no female representation, operating in a manner consistent with tokenism. By contrast, we find no evidence that if a female director leaves the board that gives rise to the probability of another female joining it, as would be expected if diversity were a goal of the firm.

Regarding Hypothesis 3.2, in the static negative binomial models of Table 6, the risk, measured as the standard deviation of the ROA, helps to explain the different proportion of women directors. Given the sign of the estimated coefficient we can affirm that companies with greater uncertainty in their results are those in which it is less likely to have a woman as a director (see Table 7). This result is consistent with statistical discrimination in the sense proposed by Schubert et al. (1999). In this respect, if women are expected to be more conservative investors than men, they will be consequently excluded from those positions more related to risks. Nevertheless, this outcome is compatible with genuine higher female risk-aversion (Bernasek, 1998; Jianakoplos \& Bernasek, 1998; Sundén \& Surette, 1998).

Once again, we can rely on the dynamic negative binomial model approach to disentangle the two alternative explanations. In order to do this, we include in the model the risk variable moderated by the presence of women on the board as stated in Hypothesis 3.2 (we estimate two different coefficients for the risk variable, one for companies with women on the board and another for those without women). In the last model on Table 8, which includes this moderating term, we observe that the risk variable is significant when there are no women on the board, but not statistically significant when the company already includes women on the board. So, when there are women on the board, the risk level of the company has no effect on the gender of new directors, while for those companies without women, higher risk on income reduces the probability of hiring additional women. This result is in line with the statistical discrimination interpretation of Schubert et al. (1999), rather than with the actual risk aversion by female executives.

\section{DISCUSSION}

In this paper, we have disentangled the relative importance of the main factors explaining the scarce presence of women on the boards of directors of the top 1000 
Spanish companies (6.61\% in 2005 and $8.66 \%$ in 2008), that is, the reduced pool of female candidates, taste-based discrimination and statistical discrimination. This is especially relevant since the first one would indicate a general problem for the society as the preferences and outlook on life that women have may be a consequence of the way they are brought up (and usually both firms and head-hunters specialized in board nominations that tend to explain the underrepresentation of women use this argument to explain it), the later ones indicates a problem of efficiency in the nomination process. This inefficiency is not just because having women necessarily have to improve business results in a direct and measurable way, but because the decision to exclude women of the process of recruiting new directors for the mere fact of being women is clearly inefficient (reduces the probability of choosing the best possible candidates for the company independently of their gender).

In fact, the results of our model estimations indicate a positive and significant relationship between the proportion of female executives in the industry and the percentage of women on the board. This result supports the reduced pool of women candidates from executive positions as a cause for the under-representation of women on the Spanish boards of directors. This is also confirmed by the positive relationship between family-based companies and the proportion of women directors. We think this effect is caused by the tendency to favour family ties, regardless of gender, when it comes to promoting directors. In this way, as in family-based firms female executive candidates to the board are chosen among the owners-managers women family members the restriction of a reduced pool of women in the executive management does not apply.

One of the important practical implications of these results is that if we want to raise the proportion of female directors it seems necessary to look for mechanisms to reduce the exclusion of women from the pool of potential candidates to join the board. On one hand, the reduced proportion of female candidates can only be resolved in the medium to long term with education and mentoring initiatives to improve their training for boards and management responsibility. Mentorship of young female managers by veteran CEO's (Lee and Nolan, 1998) could help potential future directors to built self confidence, develop particular skills, learn about industry and increase personal impact. Another way to mitigate the socio-cultural obstacles women find in the early stages leading up to their professional promotion is the implementation of polices to achieve work/life balance and to share home duties more equally between men and women. A 
possible solution to enlarge the reduced pool of female candidates is to expand the selection criteria to include other talent sources that are usually disregarded (such as human resources or customer relations managers, independent directors from liberal professionals, universities, research centres and non-profit organisations, in which women are highly represented). In the same sense, there is growing number of networking initiatives designed to help potential non-executives to enhance their credibility as candidates for board, and a growing number of non-commercial organisations developing databases of qualified women individuals interested in board positions.

Nevertheless, in order to focus on customized measures that better improve the chances of a female executive reaching the board, it would be worth analyzing how her personal (social, familiar, economic) characteristics affect her professional development, including her subjective perception of positive/negative gender discrimination measures.

Although the reduced pool of women candidates is a major cause, we find it quite improbable that the large gap existing between the scarce female representation on Spanish boards of directors and the approximately $32 \%$ of women's participation in top executive positions can only be attributed only to differences in the labour supply. In fact, results related to the rest of the hypotheses we analyze in the paper confirms that the reduced pool of candidates is not the only argument.

In this sense, there is evidence of taste-based discrimination. Moreover, we interpret the fact that older firms and more competitive sectors have a greater presence of female directors as a manifestation of the prediction from Becker's theory of discrimination (Becker, 1957). In this respect, we can point out that both competition and time seem to be playing in favour of women's presence on Spanish boards. Another relevant consequence of this finding is that the relationship of women directors and firm performance (that is out of the purpose of this paper) cannot be properly measured without controlling for this two factors that affect both the gender composition of the board and the results of the company and to the best of our knowledge no study has yet done it.

Further research on this issue could give more evidence on the presence of discriminating practices. For instance, knowing the gender composition of a company's management could help ascertain whether there is some discrimination bias in the nomination process by comparing this group with the actual board members. Event 
studies could also be helpful. Analyzing the curriculum vitae of actual candidates to a board position and the candidate finally selected could help separate the relevance given to the personal skills of candidates from the role their gender plays in the final decision. Although data on failed candidates are difficult, if not impossible, to find, one exception is the case of Mergers and Acquisitions where the board of the resulting company is generally chosen from among the boards of the original companies and, therefore, we also know the names of the former directors that are excluded of the new board.

Through the estimation of a negative binomial model, we also detect a contagion factor, according to which the presence of women on the board smoothes the way for other women joining the board. The results of the empirical model that analyses the likelihood of adding a female to the board strongly confirm that this is a true contagion rather than a consequence of unobserved heterogeneity in the sample ('spurious contagion').

We interpret this contagious effect as evidence of the possible existence of a certain underestimation of women's skills, based on the fact that the presence of women on the board contributes to reducing the bias in the perception of their abilities, since direct contact with people of the group discriminated against could reduce the effects of stereotypes and social prejudices (Bertrand, Dolly, \& Mullainathan, 2005).

Additional evidence of incorrect preconceptions about women attitudes and their capacity to hold these positions is found through a moderator effect of the presence of women on the risk variable. In this sense, although the lesser presence of women on the boards of riskier firms can be interpreted by using the explanation that women are usually more risk-averse than men (Bernasek, 1998; Jianakoplos \& Bernasek, 1998; Sundén \& Surette, 1998), we find that this negative effect disappears in the presence of women directors. The absence of a significant parameter of the interaction of women directors and risk support the theory of Schubert et al., (1999) since the prejudices concerning the female attitudes to risk would be eliminated or, at least, reduced, as the actual presence of female directors provides information on their real attitudes to risk.

These evidences on inefficiencies in the nomination process does support public policy initiatives such as the implementation of those good corporate governance practices related to transparency and objectivity in selection procedures (i.e., preparation of training programmes for Incentive and Nomination Committees to select and evaluate candidates, objectiveness and precision in directors' selection criteria, and request for public explanations from the board when women directors are few or 
nonexistent). Even establishing quotas for women may be useful, since discrimination stemming from the underestimation of women's skills can only be overcome by the presence of women on the boards that, in the medium-term, would provide more accurate information to banish biased evaluations on their capability regarding being appointed to boards of directors.

In this connection, in recent years some public measures have attempted to tackle the problem of gender discrimination on Spanish boards. Since 2006, the CNMV has required all listed companies to inform in their Annual Report in compliance with the official recommendations concerning corporate governance recommendations concerning including their board functional structure, size and gender diversity issues. Similarly, the Equality Law of 2007 established this gender balance as one of their objectives. However, we are aware that companies, for the time being, have not reacted to any of these measures. Perhaps some time is required in both cases to fulfil their aims. In this sense, a continuous monitoring of the gender composition of the companies analyzed in this study could provide us in the near future with a powerful tool to assess the success of these initiatives. Comparative research with other countries that have established a similar quotas programme, such as Norway, could help gauge the effectiveness of these kinds of measures.

Finally, we can conclude that although several theories explain the underrepresentation of women in the top corporate world relying upon adverse selection or women's incentive problems in the labour market, at least in the Spanish case the reduce pool of women executive candidates can not be claimed as the only and principal cause. On the contrary, there is a clear case of discrimination against women (taste base, statistical and mistake-based discrimination) that hinder their access to the board, and which requires active gender equality policies to reduce and remove it. The problem is much more complex and we have found evidence of several kinds of discrimination against women. This is something that academics, companies and policymakers should have in mind when trying to explain and cope with this problem.

\section{ACKNOWLEDGEMENTS}

We are grateful for the valuable comments and suggestions of C. Anderton, M. Arellano, M.F. Bagués, O. Bover, J.J. Dolado, J.A. Fernández-Cornejo, N. Rodríguez Planas, and J. Wolfers, as well as to Professor Ruth Aguilera and three anonymous referees for their helpful editorial review of the paper. 
${ }^{1}$ Furthermore, it is difficult to obtain honest answers to questions regarding unpleasant experiences like Have you suffered discrimination in your professional career? Besides, 'suffered discrimination' can have a different interpretation for each woman.

2 The term glass ceiling is thought to have first been used by two women at Hewlett-Packard in 1979, Katherine Lawrence and Marianne Schreiber, to describe how while on the surface there seemed to be a clear path of promotion, in fact women seemed to hit a point which they seemed unable to progress beyond. Later, the term was used in a March 1984 Adweek article by Gay Bryant Then the term glass ceiling became a permanent part of the American lexicon with a subsequent article in the Wall Street Journal published on 24 March 1986 by Carol Hymowitz and Timothy Schellhardt.

${ }^{3}$ SABI (Analysis System of Iberian Balances) is a database that contains general and financial information about more than 800,000 Spanish companies. The information is obtained from distinct official sources, Mercantile Registries, BORME, newspapers, etc. and is updated periodically. SABI is distributed in Spain by Informa and Bureau Van Dijk. http://www.bvdep.com/SABI.html.

${ }^{4}$ IZAR was eliminated since it was in the process of liquidation. EMYTEC Coop. Valenciana was eliminated since, according to the annual accounts of the Community of Valencia Cooperative Registry, its operating revenues in 2003 did not exceed 100 million euros.

${ }^{5}$ An alternative way to obtain data about the composition of boards of directors is the use of surveys. However, survey data have low response rates that could drastically reduce the base of analysed companies. Furthermore, as Carter et al. (2003) suggest, survey data would likely be biased towards those firms wishing to 'showcase' their diverse boards.

${ }^{6}$ For those companies with a sole administrator, they can be considered as a family-based firm when the family (at least two members) possesses a significant portion of the shares of the company, and when the function of Sole Administrator is held by one member of the family.

${ }^{7}$ These six sectors are the following: Oil and energy; Commodities, industry and construction; Consumer goods; Consumer services; Financial services and real estate agencies; Technology and telecommunications.

${ }^{8}$ We have also estimated Poisson, Zero-Inflated Poisson and Zero-Inflated Negative Binomial Regression Models. Nevertheless, using Likelihood Ratio Tests the Negative Binomial model is found to be superior to the Poisson model, while the Zero-Inflated Negative Binomial Model is superior to the Zero-Inflated Poisson and Poisson models, but no significant difference is found relative to the simpler Negative Binomial Model. Results on these models would be provided by a request to the authors.

${ }^{9}$ In order to check the consistency of the significance of the coefficients, we have estimated each model twice: first including all the independent variables; and a second one eliminating one-by-one all the nonsignificant variables. In both cases we obtain the same significant variables, which can be considered as a robustness check for the significance of the coefficients against multicolinearity. Results on these models would be provided on request by the authors.

${ }^{10}$ As a robust check of this later result and taking into account that 72 companies among our sample disappeared between 2005 and 2008, it is possible to estimate a probit/logit model on the probability of a company being closed down. Following Altman (1968), equity over debt, reserves over assets, working capital over assets, income over assets and return on assets are used as predictors of bankruptcy, as well as the number of women on the board, age of the company, industry dummies and other control variables. The result of this probit estimation reinforces our previous conclusions: younger companies and start-ups as well as a lower proportion of female directors have a higher proportion of default. 


\section{REFERENCES}

Adams, R. and Ferreira, D. 2004. Diversity and incentives in teams: Evidence from corporate boards. Working paper. Federal Reserve Bank of New York, New York.

Adler, R. 2001. Women in the executive suite correlate to high profits. Harvard Business Review, 79: 3-18.

Agrawal, A. and Knowber, C.R. 2001. Do some outside directors play a political role? Journal of Law and Economics, 44: 179-198.

Albert-Roulhac, C. 2005. Corporate governance in Europe: What's the outlook? England. Chicago: Heidrick \& Struggles International.

Brammer, S., Millington, A. and Pavelin, S. 2007. Gender and ethnic diversity among UK corporate boards. Corporate Governance: An International Review, 15(2): 393-403.

Becker, G. 1957. The economics of discrimination. $2^{\text {nd }}$ edition. Chicago: University of Chicago Press.

Bertrand, M. and Hallock, K. 2001. The gender gap in top corporate jobs. Industrial and Labor Relations Review, 55(1): 3-21.

Bertrand, M., Dolly, C. and Mullainathan, S. 2005. Implicit discrimination. The American Economic Review, 95: 94-98.

Bertrand, M., Goldin, C. and Katz, L.F. 2009. Dynamics of the Gender Gap for Young Professionals in the Corporate and Financial Sectors. NBER Working Paper Series, w14681.

Carleton W., Nelson, M. and Weisbach, M. 1998. The influence of institutions on corporate governance through private negotiations: Evidence from TIAACREFF. Journal of Finance, 53: 1335-1362.

Carter, D., Simkins, B. and Simpson, G. 2003. Corporate governance, board diversity, and firm value. Financial Review, 38: 33-53.

Carter, D, D’Souza, F., Simkins, B. and Simpson, G. 2010. The diversity of corporate board committees and firm financial performance. Corporate Governance: An International Review, forthcoming.

Catalyst. 2004. The bottom line: Connecting corporate performance and gender diversity. New York: Catalyst. 
Cavalluzzo, K., Cavalluzzo, L. and Wolken, J. 2002. Competition, Small Business Financing, and Discrimination: Evidence from a New Survey. Journal of Business, 75(4), 641-679.

Constitutional Act 3/2007 of 22 March for Effective Equality between Women and Men, BOE n 71, 23 March 2007.

Dalton, D.R., Daily, C.M., Ellstrand, A.E., and Johnson, J.L. 1998. Meta-Analytic Reviews of Board Composition, Leadership Structure, and Financial Performance. Strategic Management Journal, 19(3): 269-290

De Anca, C. 2008. Women on corporate boards of directors in Spanish listed companies. In: Vinnicombe, S., Singh, V., Burke, R., Bilimoria, D. and Huse, M. (eds.) Women on Corporate Boards of Directors: International Research and Practice, 96-107. Edward Elgar, Cheltenham.

De la Rica, S., Dolado, J., and Llorens, V. 2008. Ceilings or floors? Gender wage gaps by education in Spain. Journal of Population Economics, 21: 751-778.

Dolado, J., Felgueroso, F., and Jimeno, J. 2004. Where do women work?: Analyzing patterns in occupational segregation by gender. Annales d'economie et de statistique, 71-72: 293-315.

Erhardt, N., Verberl, J.-D., and Shrader, C. 2003. Board of director diversity and firm financial performance. Corporate Governance: An International Review, 11: 102-111.

Ethical Investment Research Service. 2004. Female Directors in the World. March 2004.

European Professional Women's Network. 2004. European board women monitor 2004. Paris: European Professional Women's Network \& Egon Zehnder International.

Farrell, K. and Hersch, P. 2005. Additions to corporate boards: The effect of gender. Journal of Corporate Finance, 11: 85-106.

Félez, M., Romero, A., Pueyo, R., and Llaría J. 2004. Gender and Boards of Directors of IBEX 35's companies. Working paper. Zaragoza: Fundación Ecología y Desarrollo.

Fryxell, G. and Lerner, L. 1989. Contrasting corporate profiles: Women and minority representation in top management positions. Journal of Business Ethics, 8: 341352. 
Garay, U. and González, M. 2008. Corporate Governance and Firm Value: The Case of Venezuela. Corporate Governance An International Review, 16: 194-209.

Gersik, K., Davis, J., Hampton, M., and Lansberg, I. 1997. Generation to generation: Life cycles of the family business. Boston MA: Harvard Business School Press.

Gillan, S. and Starks, L. 2000. Corporate governance proposals and shareholder activism: The role of institutional investors. Journal of Financial Economics, 57: 275-305.

Gómez Ansón, S. 2005. Gender diversity on boards of directos of listed companies and saving banks in Spain. Working paper, no. 12. Madrid: Fundación de Estudios Finacieros.

Harrigan, K. 1981. Numbers and positions of women elected to corporate boards. Academy of Management Journal, 24: 619-625.

Hausmann, R., Tyson, D.L., and Zahidi, S. 2009. The Global Gender Gap Report. Geneva: Word Economic Forum.

Heckman, J. 1998. Detecting discrimination. Journal of Economic Perspectives, 12: 101-116.

Jianakoplos, N.A. and Bernasek, A. 1998. Are women more risk averse? Economic Inquiry, 36: 620-630.

Johnson, J. E. V. and Powell, P. L. 1994. Decision Making, Risk and Gender: Are Managers Different? British Journal of Management, 5(2): 123-38.

Kang, H., Chen, G., and Gray, S. J. 2007. Corporate governance and board composition: Diversity and independence of Australian boards. Corporate Governance: An International Review, 15(2): 194-207.

Lee, J. and Nolan, R. 1998. The Relationship Between Mentoring and the Career Advancement of Women Administrators in Cooperative Extension. Journal of Career Development, 25: 3-13.

Linck, J., Netter, J. and Yang, T. 2008. The determinants of board structure. Journal of Financial Economics, 87: 308-328.

Long, J. S. 1997. Regression models for categorical and limited dependent variables. London: Sage.

Milliken, F. J. and Martins, L. L. 1996. Searching for common threads: Understanding the multiple effects of diversity in organizational groups. The Academy of Management Review, 21(2): 402-433. 
Morrison, A., White, R., and Van Velsor, E. 1987. Breaking the glass ceiling. New York: Addison-Wesley.

Natividad, I. 2002. Women board of directors of Spain's top companies. Washington DC: Corporate Women Directors International.

Osteryoung, J.S. and Newman, D. 1993. What is small business? The Journal of Small Business Finance, 2: 219-231.

Pearce, J. and Zahra, S. 1992. Board composition from a strategic contingency perpective. Journal of Management Studies, 29: 411-438.

Phelps, E.S. 1972. The statistical theory of racism and sexism. American Economic Review, 62: 659-661.

Point, S. and Sigh, V. 2003. Defining and Dimensionalising Diversity: Evidence form Corporate Websites across Europe. European Management Journal, 21(6): 750-761.

Powell, G. and Butterfield, A. 1994. Investigating the 'glass ceiling' phenomenon: An empirical study of actual promotions to top management. Academy of Management Journal, 37: 68-86.

Rhoades, S. 1993. The Herfindahl-Hirschman Index. Federal Reserve Bulletin, 79: 188-189.

Rodríguez Mora, J.V. 2009. The Misallocation of Talent. Els Opuscles del Centre de Recerca en Economia Internacional (CREI). Barcelona: CREI.

Ruigrok, W., Peck, S., and Tacheva, S. 2007. Nationality and gender diversity on Swiss corporate boards. Corporate Governance: An International Review, 15(4): 546557.

Singh, V. and Vinnicombre, S. 2006. The Female FTSE Report 2006. Cranfield, UK: Cranfield University.

Singh,V., Terjesen, S., and Vinnicombre, S. 2008. Newly Appointed Directors in the Boardroom: How Do Women and Men Differ? European Management Journal, 26(1): 48-58.

Schubert, R., Brown, M., Grysler, M., and Brachinger, W. 1999. Financial decisionmaking: Are women really more risk-averse? American Economic Review, 89 (2): 381-385.

Spencer Stuart. 2004. Spain 2004. Spencer Stuart Index of Board of Directors. Madrid: Spencer Stuart. 
Sundén, A. E. and Surette, B. J. 1998. Gender Differences in the Allocation of Assets in Retirement Savings Plans. American Economic Review, 88(2):207-11.

Terjesen, S. and Singh, V. 2008. Female presence on Corporate Boards: A Multicountry study of Environmental Context. Journal of Business Ethics, 83(1): 5563.

Terjesen, S., Sealy, R., and Singh, V. 2009. Women directors on corporate boards: A review and research agenda. Corporate Governance: An International Review, 17(3): 320-337.

Van der Walt, N. and Ingley, C. 2003. Board dynamics and the influence of professional background, gender and ethnic diversity of directors. Corporate Governance: An International Review, 11(3): 218-234.

Wolfers, J. 2006. Diagnosing discrimination: Stock returns and CEO gender. Journal of the European Economic Association, 4(2-3): 531-541.

Zahra, S., Neubaum, D. and Huse, M. 2000. Entrepreneurship in Medium-Size Companies: Exploring the Effects of Ownership and Governance Systems. Journal of Management, 26 (5): 947-976. 
TABLE 1

Previous research on women's presence on the boards of directors of Spanish companies.

\begin{tabular}{|c|c|c|c|}
\hline Research & Sample & $\begin{array}{c}\text { Women's } \\
\text { participation }\end{array}$ & $\begin{array}{c}\text { Boards } \\
\text { without } \\
\text { women }\end{array}$ \\
\hline Natividad (2002) & 300 companies ranked by operating revenues & $4.6 \%$ & $76 \%$ \\
\hline Ethical Investment Research Services (2004) & FTSE All World Developed Index (24 companies) & $3.8 \%$ & _ \\
\hline Félez, Romero, Pueyo, \& Llaría (2004) & Ibex -35 (35 companies) & $3.57 \%$ & $63 \%$ \\
\hline European Professional Women's Network (2004) & 250 European companies by operating revenues & $3 \%$ & $60 \%$ \\
\hline Spencer Stuart (2004) & 90 Spanish companies & $4 \%$ & $66 \%$ \\
\hline Albert-Roulhac (2005) & Ibex-35 (35 companies) & $2.6 \%$ & $69 \%$ \\
\hline Gómez Ansón (2005) & 119 Spanish listed companies & $4.04 \%$ & $68.07 \%$ \\
\hline
\end{tabular}


TABLE 2

Summary of hypothesis tested, type of discriminations involved and related variables.

\begin{tabular}{|c|c|c|c|}
\hline & Proposition 1: & Proposition 2: & Proposition 3: \\
\hline Proposition & $\begin{array}{l}\text { The reduced pool of } \\
\text { female executive } \\
\text { candidates compared to } \\
\text { men limits the number of } \\
\text { women on the Board of } \\
\text { Directors }\end{array}$ & $\begin{array}{l}\text { Lack of competition } \\
\text { hinders the presence } \\
\text { of women on the } \\
\text { board }\end{array}$ & $\begin{array}{l}\text { Lack of information } \\
\text { about actual personal } \\
\text { abilities raises barriers } \\
\text { against female } \\
\text { candidates. }\end{array}$ \\
\hline $\begin{array}{l}\text { Ultimate } \\
\text { Cause }\end{array}$ & $\begin{array}{l}\text { Discrimination on the } \\
\text { first stages of the } \\
\text { professional career } \\
\text { Adverse selection }\end{array}$ & $\begin{array}{l}\text { Taste-based } \\
\text { discrimination }\end{array}$ & $\begin{array}{l}\text { Mistake-based, statistical } \\
\text { discrimination }\end{array}$ \\
\hline Hypothesis & $\begin{array}{l}\text { H 1.1. There is a positive } \\
\text { relationship between the } \\
\text { industry proportion of } \\
\text { female executives and } \\
\text { the proportion of women } \\
\text { on the board } \\
\text { H. } 1.2 \text {. Family-based } \\
\text { firm variable has a } \\
\text { positive relationship } \\
\text { with the proportion of } \\
\text { women directors. }\end{array}$ & $\begin{array}{l}\text { H 2.1. An industry's } \\
\text { concentration has a } \\
\text { negative relationship } \\
\text { with the percentage } \\
\text { of women on the } \\
\text { board. } \\
\text { H 2.2. There is a } \\
\text { positive relationship } \\
\text { between a firm's age } \\
\text { and the proportion } \\
\text { of women directors. }\end{array}$ & $\begin{array}{l}\text { H 3.1. The absence of } \\
\text { women on the board has } \\
\text { a negative relationship } \\
\text { with the probability of } \\
\text { hiring new female } \\
\text { candidates } \\
\text { H 3.2. The risk level of } \\
\text { the firm has no effect on } \\
\text { the gender of new } \\
\text { directors when there are } \\
\text { already women on the } \\
\text { board }\end{array}$ \\
\hline
\end{tabular}


For the flows of directors we used a sub-sample of 992 companies: from the original sample of 1148 nonfinancial companies, we have excluded those which were extinct in 2008 and those companies whose boards were entirely formed by institutional board members.

Boards of Directors 2005 and 2008. Descriptive statistics and flows of directors from 2005 to 2008.

\begin{tabular}{|c|c|c|c|c|c|c|c|c|c|c|}
\hline \multirow[b]{2}{*}{ Variable } & \multicolumn{5}{|c|}{2005} & \multicolumn{5}{|c|}{2008} \\
\hline & Sum & Mean $\mathbf{S}$ & St. Dev. & Min. & Max. & Sum & Mean & $\begin{array}{c}\text { St. } \\
\text { Dev. }\end{array}$ & Min. & Max. \\
\hline Number of board members & 6525 & 6.01 & 4.59 & 1 & 57 & 5806 & 5.85 & 4.49 & 1 & 55 \\
\hline Number of direct board members & 6003 & 5.53 & 4.08 & 1 & 50 & 5277 & 5.32 & 3.98 & 1 & 47 \\
\hline Number of female direct board members & 397 & 0.37 & 0.82 & 0 & 6 & 457 & 0.46 & 0.95 & 0 & 10 \\
\hline Number of male direct board members & 5606 & 5.16 & 3.89 & 0 & 47 & 4820 & 4.86 & 3.66 & 0 & 42 \\
\hline Boards without women & 830 & 76.5 & 0.42 & 0 & 1 & 708 & 71.4 & 0.45 & 0 & 1 \\
\hline Boards with one woman & 174 & 16.0 & 0.37 & 0 & 1 & 185 & 18.6 & 0.39 & 0 & 1 \\
\hline Boards & 44 & 4.1 & 0.20 & 0 & 1 & 59 & 5.9 & 0.24 & 0 & 1 \\
\hline Boards wit & 37 & 3.4 & 0.18 & 0 & 1 & 40 & 4.0 & 0.20 & 0 & 1 \\
\hline \multirow[t]{2}{*}{$\%$ of women among direct members } & & 6.61 & 13.96 & 0 & 100 & & 8.66 & 15.19 & 0 & 100 \\
\hline & & & & Sum & & Mean & St. Dev. & Min & Max & \\
\hline \multicolumn{4}{|c|}{ Number of directors leaving the board 2005-2008 } & 261 & & 2.29 & 2.52 & $\overline{0}$ & 18 & \\
\hline \multicolumn{4}{|c|}{ Number of directors entering the board 2005-2008 } & 189 & & 1.65 & 2.12 & 0 & 16 & \\
\hline \multicolumn{4}{|c|}{ Number of male directors leaving the board 2005-2008 } & 248 & & 2.16 & 2.41 & 0 & 18 & \\
\hline \multicolumn{4}{|c|}{ Number of male directors entering the board 2005-2008 } & 169 & & 1.48 & 1.92 & 0 & 15 & \\
\hline \multicolumn{4}{|c|}{ Number of female directors leaving the board 2005-2008 } & 13 & & 0.12 & 0.44 & 0 & 5 & \\
\hline \multicolumn{4}{|c|}{ Number of female directors entering the board 2005-2008 } & 19 & & 0.17 & 0.52 & 0 & 6 & \\
\hline
\end{tabular}


TABLE 4

Descriptive statistics

\begin{tabular}{|c|c|c|c|c|c|c|c|c|}
\hline & \multicolumn{4}{|c|}{ Total } & \multicolumn{4}{|c|}{ Family-based } \\
\hline & \multicolumn{2}{|c|}{$\begin{array}{c}2005 \\
n=1085\end{array}$} & \multicolumn{2}{|c|}{$\begin{array}{c}2008 \\
n=992\end{array}$} & \multicolumn{2}{|c|}{$\begin{array}{c}2005 \\
n=244\end{array}$} & \multicolumn{2}{|c|}{$\begin{array}{c}2008 \\
n=233\end{array}$} \\
\hline & Mean & St.Dev. & Mean & St.Dev. & Mean & St.Dev. & Mean & St.Dev. \\
\hline Total assets Th.€ (t-4,t-2) & 683434 & 3460024 & 770893 & 3361705 & 400395 & 1010370 & 549554 & 1347437 \\
\hline Return on Assets $(\mathrm{t}-4, \mathrm{t}-2)$ & 5.52 & 9.96 & 5.50 & 34.56 & 7.23 & 8.08 & 7.72 & 9.36 \\
\hline St. Deviation Return on Assets (t-14,t-2) & 6.70 & 14.24 & 6.72 & 19.01 & 4.97 & 5.02 & 4.56 & 4.07 \\
\hline Indebtness Ratio $(\mathrm{t}-4, \mathrm{t}-2)$ & 0.70 & 0.25 & 0.71 & 0.40 & 0.65 & 0.21 & 0.63 & 0.20 \\
\hline Productivity by Employee (t-4,t-2) & 2803 & 18628 & 3368 & 16185 & 806 & 2058 & 1525 & 6935 \\
\hline \multirow[t]{4}{*}{ Firm Age } & 29.29 & 21.98 & 32.31 & 22.00 & 33.01 & 20.32 & 35.82 & 20.26 \\
\hline & \multicolumn{4}{|c|}{ Listed } & \multicolumn{4}{|c|}{ Cooperative } \\
\hline & \multicolumn{2}{|c|}{$\begin{array}{l}2005 \\
\boldsymbol{n}=\mathbf{5 8}\end{array}$} & \multicolumn{2}{|c|}{$\begin{array}{c}2008 \\
\boldsymbol{n}=\mathbf{5 9}\end{array}$} & \multicolumn{2}{|c|}{$\begin{array}{l}2005 \\
n=15\end{array}$} & \multicolumn{2}{|c|}{$\begin{array}{l}2008 \\
n=16\end{array}$} \\
\hline & Mean & St.Dev. & Mean & St.Dev. & Mean & St.Dev. & Mean & St.Dev. \\
\hline Total assets Th.€ $(\mathrm{t}-4, \mathrm{t}-2)$ & 5335793 & 12800000 & 5531110 & 11800000 & 406328 & 859930 & 525313 & 1043272 \\
\hline Return on Assets (t-4,t-2) & 7.14 & 5.92 & 9.24 & 8.18 & 3.23 & 3.73 & 3.85 & 4.87 \\
\hline St. Deviation Return on Assets $(\mathrm{t}-14, \mathrm{t}-2)$ & 4.45 & 4.58 & 4.10 & 3.29 & 1.92 & 1.68 & 1.67 & 1.21 \\
\hline Indebtness Ratio $(\mathrm{t}-4, \mathrm{t}-2)$ & 0.62 & 0.15 & 0.61 & 0.18 & 0.65 & 0.10 & 0.66 & 0.12 \\
\hline Productivity by Employee (t-4,t-2) & 497 & 695 & 498 & 574 & 814 & 703 & 1001 & 804 \\
\hline Firm Age (Log) & 52.93 & 29.99 & 54.31 & 30.63 & 43.20 & 16.17 & 46.31 & 15.63 \\
\hline
\end{tabular}


TABLE 5

Correlation matrix

1 Number of direct members of the board

2 Listed firm

3 Cooperative

4 Family-Based firm

5 Independence Indicator

6 Firm Age (Log)

7 Total assets Th.€ (t-4.t-2) (Log)

8 Return on Assets (t-4.t-2)

9 St. Deviation Return on Assets (t-14.t-2)(Log)

10 Indebtness ratio (t-4.t-2)

11 Productivity by employee (t-4.t-2) (Log)

12 Proportion of women executives in industry

$13 \mathrm{HHI}(\mathrm{Log})$

14 Public contracts over income (2004-2006) (\%)

\begin{tabular}{|c|c|c|c|c|c|c|c|c|c|c|c|c|}
\hline 1 & 3 & 4 & 5 & 6 & 7 & 8 & 9 & 10 & 11 & 12 & 13 & 14 \\
\hline 1 & & & & & & & & & & & & \\
\hline .44 & & & & & & & & & & & & \\
\hline $.10-.03$ & 1 & & & & & & & & & & & \\
\hline .01 .03 & -.06 & 1 & & & & & & & & & & \\
\hline .29 .47 & .02 & .15 & 1 & & & & & & & & & \\
\hline .21 .22 & .09 & .13 & .17 & 1 & & & & & & & & \\
\hline $\begin{array}{ll}.39 & .41\end{array}$ & -.01 & -.03 & .20 & .20 & 1 & & & & & & & \\
\hline .05 & -.03 & .07 & .03 & .17 & .04 & 1 & & & & & & \\
\hline$-.16-.07$ & -.15 & -.09 & -.15 & -.02 & -.12 & .12 & 1 & & & & & \\
\hline$-.08-.06$ & -.02 & -.10 & -.08 & -.16 & -.10 & -.43 & .02 & 1 & & & & \\
\hline$-.10-.13$ & .01 & -.14 & -.06 & -.22 & -.09 & -.01 & -.03 & .12 & 1 & & & \\
\hline .06 & -.03 & .03 & -.02 & -.00 & -.04 & .06 & .05 & -.08 & .02 & 1 & & \\
\hline$-.03-.05$ & -.01 & -.14 & .02 & & .12 & .03 & .08 & -.04 & & .08 & 1 & \\
\hline $.03-.01$ & -.02 & .04 & -.02 & .05 & .05 & -.01 & -.02 & .04 & $-10-$. & .07 & -.15 & 1 \\
\hline
\end{tabular}


TABLE 6

Negative binomial regression models on the number of women on the board (with exposure to the number of direct members of the board)

\begin{tabular}{|c|c|c|c|c|}
\hline & \multicolumn{2}{|c|}{$\begin{array}{l}\text { Pooled Data } \\
(2005-2008)\end{array}$} & \multicolumn{2}{|c|}{$\begin{array}{l}\text { Panel Data } \\
(2005-2008)\end{array}$} \\
\hline & Model & & Model & \\
\hline Constant & -2.89 & & -3.19 & \\
\hline Number of direct members of the board & 0.05 & ** & 0.05 & * \\
\hline Number of direct members of the board (squared) & -0.01 & ** & -0.00 & \\
\hline Listed firm & -0.59 & * & -0.28 & \\
\hline Cooperative & 1.99 & $* * *$ & 1.15 & $\star *$ \\
\hline Family-Based firm & 1.35 & $* * *$ & 0.98 & *** \\
\hline Independence Indicator & -0.12 & * & -0.08 & * \\
\hline Firm Age (Log) & 0.20 & * & 0.22 & * \\
\hline Total assets Th.€ $(\mathrm{t}-4, \mathrm{t}-2)(\mathrm{Log})$ & -0.06 & $\dagger$ & -0.07 & \\
\hline Return on Assets $(t-4, t-2)$ & -0.00 & & -0.00 & \\
\hline St. Deviation Return on Assets $(t-14, t-2)(\log )$ & -0.12 & ** & -0.10 & $\dagger$ \\
\hline Indebtness ratio (t-4,t-2) & -0.01 & & 0.11 & \\
\hline Productivity by employee (t-4,t-2) (Log) & -0.02 & & 0.01 & \\
\hline $\mathrm{HHI}(\log )$ & -0.10 & * & -0.10 & $\dagger$ \\
\hline Proportion of women executives in industry & 0.90 & * & 1.12 & * \\
\hline $\begin{array}{l}\text { Public contracts over income (2004-2006) } \\
(\%)^{\star} \text { Year } 2008\end{array}$ & -0.00 & & -0.00 & \\
\hline Year 2008 & 0.37 & $\star * \star *$ & 0.26 & 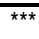 \\
\hline Industry effects & Yes & & Yes & \\
\hline Company random effects & No & & Yes & \\
\hline Contagion effect $(\alpha)$ & 0.45 & $* \star * *$ & 1.28 & *** \\
\hline Number of observations & 1730 & & 1730 & \\
\hline LR test & 204.01 & $* * *$ & 120.77 & *** \\
\hline Wald test & 254.85 & $* * *$ & 121.45 & *** \\
\hline LR test against a Poisson & 38.87 & *** & 204.17 & *** \\
\hline LR test against a Zero-Infl. Negative Binomial & 2.65 & & 0.25 & \\
\hline
\end{tabular}

Estimations obtained with STATA v.9. A robust variance-covariance matrix is used in order to correct heteroscedasticity and correlation among directors of the same board.

For each variable, an LR test has been performed between a model with and without this variable. Stars give the significant level of the null hypothesis rejection: $0.1 \% * * *, 1 \% * *, 5 \% *$ and $10 \%$ †. 


\section{Probability of a board position being held by a woman.}

Influence of Board Size (upper left-hand side), Firm age (upper right-hand side), Proportion of female executives in the industry (lower left-hand side), Industrial Concentration Index (lower right-

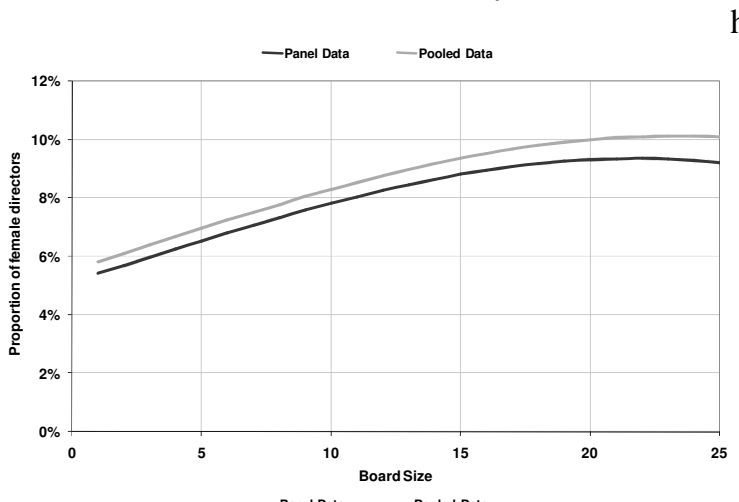
hand side)
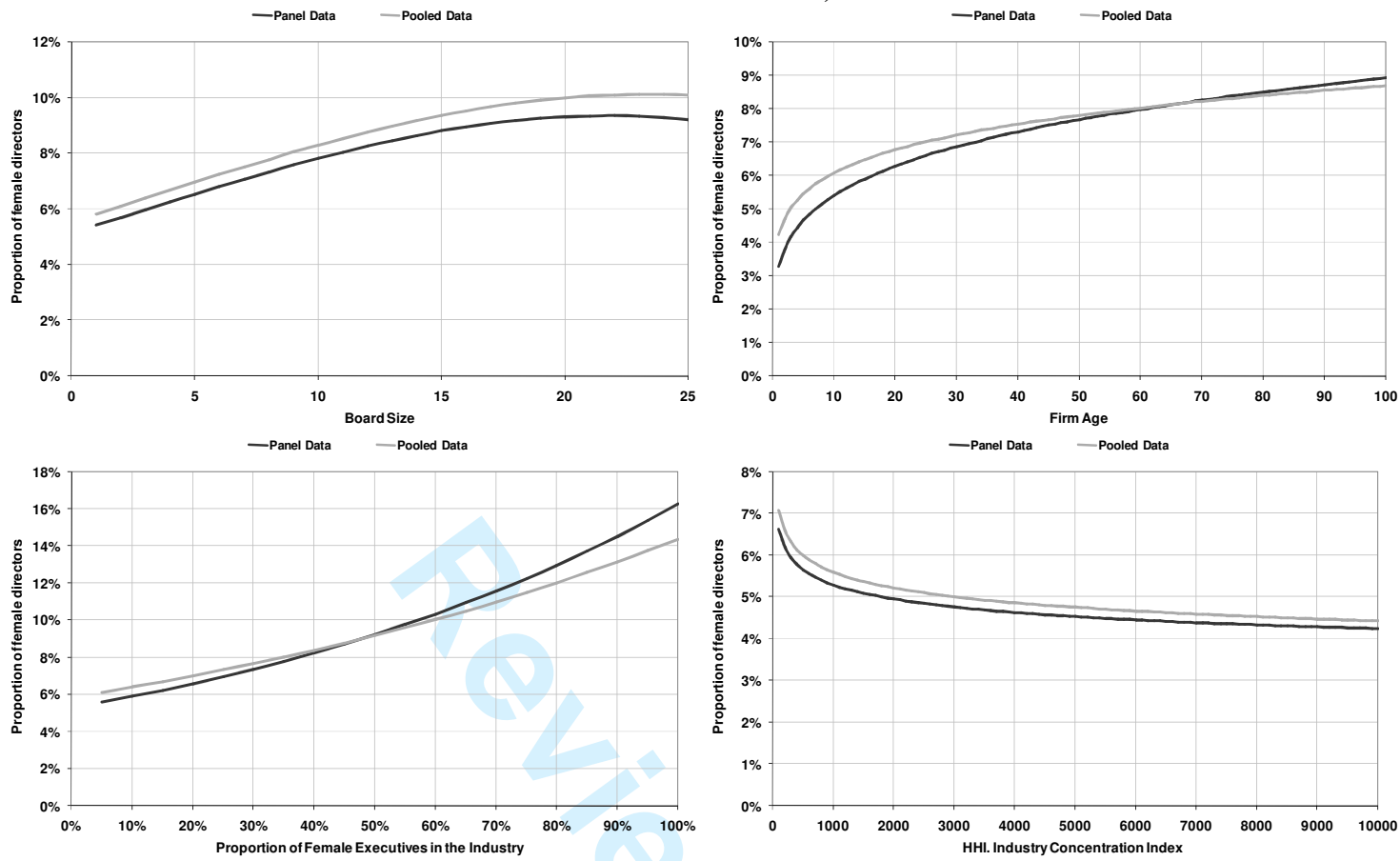

Probabilities computed for the models in Table 4 (models I and II). A representative company in 2008 has been considered to be a non-family-based one, that is not listed and not a cooperative, with an independence indicator equal to $\mathrm{C}$, mean risk and assets, 24 years old, and belonging to the category of Consumer Services, with the mean proportion of female executives and sales concentration and with five direct members of the board (mean and mode of each quantitative and qualitative variable respectively). All variables are fixed to the base case and moving each variable one by one. 
TABLE 7

Probability of a board position being held by a woman. Marginal effects of independent variables.

\begin{tabular}{|c|c|c|c|c|c|c|c|}
\hline & & Panel Data & Pooled Data & & & Panel Data & Pooled Data \\
\hline \multirow[t]{6}{*}{ St. dev. ROA (Log) } & & & & Family-based & & & \\
\hline & $\mu-2 \sigma$ & $7.90 \%$ & $8.70 \%$ & & No & $6.53 \%$ & $6.97 \%$ \\
\hline & $\mu-\sigma$ & $7.14 \%$ & $7.74 \%$ & & Yes & $17.28 \%$ & $17.24 \%$ \\
\hline & $\mu$ & $6.48 \%$ & $6.90 \%$ & Cooperative & & & \\
\hline & $\mu+\sigma$ & $5.88 \%$ & $6.13 \%$ & & No & $6.53 \%$ & $6.97 \%$ \\
\hline & $\mu+2 \sigma$ & $5.33 \%$ & $5.45 \%$ & & Yes & $20.48 \%$ & $20.72 \%$ \\
\hline \multirow[t]{6}{*}{ Total Assets. Th. Eur. (Log) } & & & & Year & & & \\
\hline & $\mu-2 \sigma$ & $8.06 \%$ & $8.46 \%$ & & 2005 & $6.27 \%$ & $6.28 \%$ \\
\hline & $\mu-\sigma$ & $7.28 \%$ & $7.70 \%$ & & 2008 & $8.05 \%$ & $8.66 \%$ \\
\hline & $\mu$ & $6.57 \%$ & $7.00 \%$ & Listed & & & \\
\hline & $\mu+\sigma$ & $5.94 \%$ & $6.36 \%$ & & No & $6.58 \%$ & $6.97 \%$ \\
\hline & $\mu+2 \sigma$ & $5.73 \%$ & $6.16 \%$ & & Yes & $5.11 \%$ & $4.83 \%$ \\
\hline \multicolumn{4}{|l|}{ Industrial sector } & Independence & & & \\
\hline \multicolumn{2}{|c|}{ Financial services and real estate agencies } & $8.15 \%$ & $9.69 \%$ & & $\mathrm{~A}+$ & $4.36 \%$ & $4.64 \%$ \\
\hline \multicolumn{2}{|c|}{ Oil and energy } & $7.14 \%$ & $7.91 \%$ & & A & $4.73 \%$ & $5.03 \%$ \\
\hline \multicolumn{2}{|c|}{ Consumer services } & $6.53 \%$ & $6.97 \%$ & & A- & $5.13 \%$ & $5.45 \%$ \\
\hline \multicolumn{2}{|c|}{ Consumer goods } & $6.24 \%$ & $7.06 \%$ & & $\mathrm{~B}+$ & $5.56 \%$ & $5.90 \%$ \\
\hline \multicolumn{2}{|c|}{ Commodities, industry and construction } & $4.18 \%$ & $4.92 \%$ & & B- & $6.03 \%$ & $6.41 \%$ \\
\hline \multicolumn{2}{|c|}{ Technology and telecommunications } & $4.33 \%$ & $4.05 \%$ & & $\mathrm{C}$ & $6.53 \%$ & $6.97 \%$ \\
\hline
\end{tabular}

Probabilities computed for the models in Table 4 (models I and II). A representative company in 2008 has been considered to be a non-family-based one, that is not listed and not a cooperative, with an independence indicator equal to $\mathrm{C}$, mean risk and assets, 24 years old, and belonging to the category of Consumer Services, with the mean proportion of female executives and sales concentration and with five direct members of the board (mean and mode of each quantitative and qualitative variable respectively). All variables are fixed to the base case and moving each variable one by one. 
Variables

Constant

$\%$ women among direct members in 2005

Number of female departures

Number of direct members of the board

Listed firm

Family-based firm

Independence indicator

Cooperative

Firm size

Return on assets (2001-2003) (\%)

St. deviation return on assets (1991-2003) ( Log)

St. deviation (Companies with female directors in 2005)

St. deviation (Companies without female directors in 2005)

Productivity by employee (2001-2003) (Log)

Indebtedness ratio (2001-2003)

Firm age (Log)

Public contracts over income (2004-2006) (\%)

Industry effects

$\alpha$ (contagion effect)

LR test

Wald test

TABLE 8

\section{to 2008}

Model III Negative Binominal

(All Variables) (Only Significant) (Only Significant)
$-2.08$
$1.58 *$
$-0.00$
0.01
$-0.05$
0.27
$-0.03$
$1.29 *$
$-0.02$
0.02
$-0.07$

$-1.88$

$-1.76$

$2.25 * *$

$1.82 * *$

\section{-0.11 *}

\section{$-0.05$}

-0.21 *

$-0.02$

0.32

$-0.08$

$-0.85$

YES

YES

YES

0.04

0.03

$43.60 * *$

$33.95 *$

$39.18 * *$

$61.69 * * \quad 46.96$ **

$44.20 * *$

Models include an exposure factor of total directors entering the board between 2005 and 2008

Estimations obtained with STATA v.9. A robust variance-covariance matrix is used in order to correct heteroscedasticity and correlation among directors of the same board.

For each variable, an LR test has been performed between a model with and without this variable.

Stars give the significant level of the null hypothesis rejection: $0.1 \% * * *, 1 \% * *, 5 \% *$ and $10 \%+$. 